\title{
A Question of Access: Finding Information Books for Emergent Readers
}

\author{
Patricia A. Larkin-Lieffers \\ University of Alberta
}

\begin{abstract}
Emergent readers enjoy and benefit from reading age appropriate information books, and there are many books published for this cohort. However, the few studies conducted on access suggest that opportunities to find these books are limited. Early reading instruction usually favours fiction, while school library collections may be limited due to budget constraints. Retail selection is poor, and few awards recognize this genre. Public library access may be compromised due to budget issues, library design, fiction in displays, and parental behaviour. More research to clarify issues regarding access is needed to improve young children's opportunities to find information books.
\end{abstract}

It is a delight for a parent, teacher, or librarian, to see a very young child's face light up when they find a book that sparks their interest. It is this interest that feeds young children's imaginations and propels them to want to learn to read. The mainstay of children's early reading materials has been storybooks, and school and public libraries have well-stocked children's picture book selections. But as some parents are vividly aware, there are children whose passion is for a topic of non-fiction - dinosaurs, trucks, animals, and many other subjects. For these emergent readers, information books are much more appealing and useful. Young children enjoy them for their age appropriate content and illustrations, and the practice they gain from reading them is preparation for the demands of science and social studies education in elementary school. For those readers who like facts better than fiction, such information books also provide vital 
motivation and practice in simply learning to read. With today's focus on the importance of literacy at both the personal and societal level, emergent readers need opportunities to read these books, as well as fiction. But how easy is it for young children to find information books in their schools, public libraries, and bookstores?

I first became interested in the availability of information books for young children as a graduate student in Library and Information Studies. This interest led me to look at public library children's areas and how they make non-fiction materials available to five and six year old readers. I found that aspects of library design, such as the location, height, and display format of the children's area shelves, tended to favour fiction over non-fiction books. As well, my observations of young children's browsing behaviour showed that neither they, nor their parents, were finding information books. This led me to question if these materials for emergent readers were difficult to find in other venues as well. A search of the literature for research on this topic showed that studies were few, and their results were not encouraging.

This paper discusses the numerous studies that support the value of information books for emergent readers, and provides a glimpse into the publishing world for this age group to show the range of books available for them. I then review the research, and provide some observations about how easy, or difficult, it is to find these books in schools, bookstores, and libraries. From this, possible areas of further research are suggested, to point the way for parents, teachers and librarians to improve young children's access to age appropriate information books.

\section{Why only stories? The shift toward inclusion of information books in early reading instruction}

In Kindergarten and Grade 1, it has been the prevailing preference that stories rather than information books should be used to teach reading (Pappas, 1993; Caswell and Duke, 1998; Doiron, 2003; Putnam, 1991; Venezky, 2000). Pappas (1991) noted that "narrative as primary" (p. 449) doctrine assumed that stories were more basic to young children's developmental stage of learning (e.g. Egan, 1988; Adams, 1990 in Pappas, 1991) and that children could not understand the different linguistic structure of nonnarrative. Additionally, research concerning older students and expository reading (e.g. Hidi and Hildyard, 1983; Langer, 1985; Duke and Kays, 1998) showed that students' 
skill with these texts lagged behind those for narrative, often referred to as the "fourth grade slump" (Palmer and Stewart, 2003, p. 39). This was seen as further indication of young children's inability to handle non-narrative (Pappas 1991). It was also assumed that young children preferred narrative (e.g. Egan; Pappas, 1993).

These assumptions have been questioned by some researchers in emergent literacy. Pappas (1993) and Richgels (2002) discussed studies that show preschoolers have a sense of the different forms and uses of written language (Bissex (1980) and Harste, Burke and Woodward (1983), in Pappas, 1993 and Richgels, 2002). Pappas (1991, 1993) noted that young children are capable of recognizing and using different oral forms of communication, and she theorized that they may appreciate different written genres as well. She demonstrated that kindergartners could effectively use coreferentiality and co-classification processes in pretend readings of stories and information books respectively, and could adjust meanings of words depending on their use in narrative or non-narrative. She thus concluded that they were as capable of negotiating non-narrative as stories. Duke and Kays (1998) also showed, through teacher read-alouds followed by pretend readings, that kindergartners were capable of learning informational text style. Tower (2002) found similar results with preschoolers, and refuted the assertion that very young children search for narrative style in every book because that is what they prefer and are capable of using. Pappas (1993) proposed that emphasis on stories in the early school years may cause informational text capability to weaken, and the aforementioned older students' lack of skill with it may be a result of this emphasis on "narrative as primary" rather than an indication of it.

Inclusion of both narrative and expository text for the emergent reader has thus been proposed by many researchers (e.g. Pappas, 1991; Sanacore, 1991; Caswell and Duke, 1998; Duke and Kays, 1998; Guillaume, 1998; Richgels, 2002; Tower, 2002; Duke, 2004; Moss, 1995, 2004a,b; Palmer and Stewart, 2005). Pappas (1993) and Duke and Kays (1998) showed that children develop expository text skill with more exposure to the texts. Rosenblatt (1991) distinguished between two types of reading: efferent, or reading for information, and aesthetic, which focuses on thoughts and emotions during reading. She remarked that these two approaches, usually applied to informational and narrative texts respectively, "are not contradictory activities" (p. 446) but can operate 
together, and it is important to teach children "the ability to adopt the stance on the continuum appropriate to their particular personal purposes and to the situation" (p. 448). In Tower's study (2002), preschool children responded to a variety of information books both efferently and aesthetically, and personal experience with the topic was often the catalyst for a stronger aesthetic response. Meek (1996) stated that children can learn from "all kinds of writing" (p. 29), which provide opportunities to refine use of various genre styles. Furthermore, children who read a variety of materials show higher academic success than those who have narrower exposure (Dreher, 2003). Research and theory thus suggest that young children can negotiate and would benefit from exposure to a broad range of both narrative and expository texts.

Pappas (1993) also found that the majority of children in her study preferred the information texts over the stories, a finding noted in other studies, both for emergent readers (e.g. Caswell and Duke, 1998; Palmer and Stewart, 2003) and for some older students (e.g. Sanacore, 1991; Beers, 1996a,b; Jobe and Dayton-Sakari, 2002; Doiron, 2003). Preference for non-fiction books, sometimes paired with hands-on activities, has been well documented for reluctant or struggling readers (Jobe and Dayton-Sakari, 1999, 2002; Dayton-Sakari and Jobe, 2003; Beers, 1996a,b; Dreher, 2003; Fisher, 2004). While information content has been emphasized, the format itself, with the preponderance of pictures and short discrete textual units, may also be more manageable for some readers (Dayton-Sakari and Jobe, 2003). Some studies have linked fiction or non-fiction preference to gender, with young girls tending toward the former and boys typically preferring the latter (e.g. Childress, 1985; Hartlage-Striby, 2001). While these tendencies may be indicators in some classroom situations, reading choices are highly personalized, and stereotyping of these preferences could be limiting to those at whom they are aimed.

The importance of children's preference for genre and topic should not be underestimated. Interest can be a strong motivating force for learning to read (Jobe and Dayton-Sakari, 2002; Haycock, 2003; M. Mackey, personal communication, March 8, 2005). Introducing informational books into the primary classroom may tap into the interests of students, especially those who do not enjoy stories or who prefer a variety of reading materials. Caswell and Duke (1998), for example, described two struggling beginning readers who, when they switched from narrative to informational text, showed 
considerable improvement in skill and attitude towards reading. Jobe and Dayton-Sakari $(1999,2002)$ emphasized that many reluctant readers are externally oriented, fact-based thinkers who therefore prefer non-fiction. Doiron (2003) also called for more use of information books to motivate young readers. Allowing some of this to be free reading may be a particularly effective means to develop interest in voluntary reading (Krashen, 2004; Worthy, 1996; Worthy, Turner and Moorman, 1998). Television may also introduce topics of interest to a young child, and a motivation for seeking further information in books (M. Mackey, personal communication, March 8, 2005; Giblin, 2000).

The importance of interest for motivating students to read is also crucial as they progress through the elementary grades. Academic success and reading competence have been tied to amount read (Worthy, Turner and Moorman, 1998; Krashen, 2002, 2004); Dreher (2003) noted that poor readers often avoid reading, thus compounding their problems. Ross (1995) stressed the role of series books, such as Nancy Drew mysteries, in providing the volume of repetitive reading needed to entrench understanding of narrative style in developing readers. Personal engagement with text that is interesting is “an essential component of avid reading” (Worthy, Turner and Moorman, 1998, p. 296; Allington, 1994), which then provides this sustained practice. A dramatic example of this is Fink's (1995) documentation of the reading lives of twelve successful adult professionals with dyslexia, who on average learned to read three or four years later than their peers. They attributed their ability to learn to read despite these problems, not to specific skill building exercises, but to the opportunity to read voraciously about what interested them. Sadly, for some this reading happened outside of school, raising the question of what happens in the school environment that discourages this type of enjoyable exploration. In any context, however, whether school or library, introducing emergent readers to texts that appeal to them is a powerful means of encouraging initial interest, ongoing persistence, and engagement in the reading process.

The advantage of including information books along with stories in the reading lives of young children is therefore clear: young children are capable of negotiating both kinds of text, practice with both texts prepares them for the more demanding reading of 
later school years, and, most importantly, they enjoy it. This interest can be a strong motivation to read more, thus strengthening literacy skills throughout their school years. A glimpse into the publishing world of children's non-fiction

Non-fiction was, for many years, the neglected side of children's literature (Freeman, 2003; Teale, 1991). There was little that was aimed at children, and what was used by students was often textbook or encyclopaedic in writing style (Freeman), usually devoid of good illustrations (Spink, 1996). The last decades have seen a dramatic improvement in selection and quality of children's non-fiction available, due to several factors.

In the late 1950s, the United States government, in response to the space race, passed the National Defense Education Act which included allotting money for school libraries to buy science books. This prompted a rush in publication of series science books for children (Giblin, 2000). Again in the 1960s, more government money through President Johnson's “Great Society” program was aimed at children’s books, including non-fiction (Giblin). These two developments helped to initiate the surge in publication of non-fiction for children in the United States. At this time, Canada's children's publication industry was very small. In 1968, for example, the total number of children's books published in Canada was only 47, compared to 3874 American titles and 2075 British titles (MacSkimming, 2003, in Mackey, 2005). Canada produced more school textbooks (207) than children's books (MacSkimming, 2003, in Mackey, 2005).

In the 1970s and 1980s, federal funding in the United States for libraries decreased (Giblin, 2000; Hade, 2002), and publishers moved to include the consumer bookstore market (Giblin). This trend was evident in other countries, such as Great Britain and Canada, as well. Books had to be colourful and attractive to buyers in the competition for other consumer goods (Giblin). This trend towards visual appeal was coupled with innovations in technology, including the use of photographs and computer aided design (Freeman, 2003). For example, books such as the immensely popular British Dorling Kindersley Eyewitness series which began publication in 1988 (DK Publishing Inc., 2006) placed the illustrations in the forefront and used small, concise sections of text for commentary (Giblin). Peter Kindersley noted that their publishing philosophy was that "information is better communicated through pictures, initially. 
Most of our world has believed up until now that the word should come first, and then only supplied some pictures if they thought them necessary" (Goldenberg, 1992, p. 297). Along with this emphasis on quality illustration was a change in writing style, from listing facts toward engagement of the reader into the book (Freeman), to show that even mundane topics could be interesting (Spink,1996).

There is now a wide range of children's non-fiction formats, including factual information books; informational storybooks (Leal, 1993) (also referred to as narrativeinformational books (Duke, 2000), info-fiction, or narrative non-fiction (Bainbridge and Malicky, 2002)), which combine facts in a picture book story; photo-documentaries; experiment and activity books; field guides; biographies; journals and first person commentary; concept books; how-to books; and question and answer (Freeman, 2003; Bainbridge and Malicky). Additions such as a table of contents, index, glossaries, list of sources, and the like also were introduced, coupled with a continued emphasis on accuracy of information (Freeman).

This interest in information books for children has continued, driven in part by the rapid scientific and technological changes of this era. Competition with television and the Internet particularly for children eight and older has also prompted innovations in non-fiction books (Beer, 2004a,b); interactive books, which mimic some aspects of the Internet, have been a more recent popular choice (Beer, 2004a,b; Elleman, 1998). The entertainment value of books has thus been emphasized (Beer, 2004a), as well as content. Of particular concern is the need to be up-to-date, to compete with the Internet for relevance.

Growth in trade non-fiction books for children has also been motivated by the increased presence of these books in the classroom (Palmer and Stewart, 2003; Raugust, 2002), and parents' interest in providing their children with school related (Engelhardt, 1991; Beer, 2004b) reading materials at home. Curriculum needs drive much of the choice of topics in children's informational materials (Beer, 2004a). Television, as well, may spawn books that are based on series or characters (Giblin, 2000; K. Larkin, personal communication, April 12, 2005). Old standby topics include dinosaurs, animals, things that go, and so on, but anything new and innovative is considered a possible publication choice (Beer, 2004a; Rodgers, 2003) as long as it is seen as potentially profitable. 
However, while past accepted levels of profitability hovered around four percent, more recently the expected level is twelve to fifteen percent (Hade, 2002), reducing the likelihood that a fringe topic will be considered for publication (Elleman, 1998).

Although the most supplied age cohorts are those in older elementary and high school, the book market for early readers has been a particular focus for publishers for many years. Teale noted in a 1991 article that the most noticeable change in the explosion of information books published in the United States was the numbers aimed at preschool and primary aged children. More recently, Beer (2004b) stated that publishers in Great Britain view the five to eight age range as an under-supplied cohort, and therefore a publishing growth opportunity. This focus may be a result of several factors. Books to fulfill curriculum requirements are now a part of the early school years; the Grade 1 curriculum in Alberta, for example, includes such science topics as "needs of plants and animals" and "seasons" (Alberta Learning, 2004a). Consequently there has been a need for inexpensive information books to meet this type of curricular demand (Lempke, 2003). As well, Internet use for younger children is low (Beer, 2004b), both because parents and teachers tend to supervise these children more heavily, and because the children's search skills are still rudimentary (Levy, 2002). Therefore these children rely more heavily on books for their information interests.

Information books for beginning readers have special requirements for both text and illustration. Eye-catching visuals on the cover and inside play a strong role in initial attraction. While kindergartners can understand fairly complex books when they are read aloud by a parent or teacher, and appreciate good illustrations in any level of information book, the ones they read for themselves must use simple, familiar language. As a consequence, books must discuss familiar topics, or ones that are introduced to the class in the curriculum (Moore, 2003). However, the text must be interesting and not simplistic, as emergent readers' interest and understanding often outstrip their reading ability. The page layout needs to be simple and consistent, and the text well spaced. Since beginning readers infer much information, particularly vocabulary, about the text from the illustrations (Moore; Tower, 2002) the illustrations must clearly fit with and support the text. Too many items in the picture or a lack of focal point may confuse rather than aid comprehension. 
The publishing world for children also includes lighter fare such as magazines and workbooks or sticker books. For information topics, magazines such as Canada's Chickadee, Owl, and Your Big Backyard deal with nature issues, while others such as Australia's Scientriffic, American National Geographic Kids and Kids Discover, and Canada's YES Mag offer a range of articles on science, the arts, geography and history. Space, Nintendo, Lego and other topics are also covered in various publications. Magazines are popular with young children and can be an effective adjunct to other text materials. Workbooks and sticker books provide activities along with factual text and are also a popular and inexpensive source of information for young children. These often focus on animals, trucks, space, castles and knights, and the like.

The book publishing world for children's information needs is thus active and productive. Hepler (2003) noted that in 2001 about 9000 children's books were published in the United States, and that "well over half ... were trade, series, or reference non-fiction titles. The Library of Congress (2002) reported that 'the split in our juvenile cataloguing has changed from about $50-50$ in the early 1990 s to nearly 60 percent' in favour of non-fiction titles" (Hepler, p. 3). Although the United States continues to be a dominant supplier of children's books to Canada (McKechnie, 2004), a review of 2004 publishing statistics showed that Canadian publishers produced over 600 titles for children that year, a huge increase from the numbers a few decades previously (Mackey, 2005). Proportions of fiction to non-fiction have been somewhat similar to those in the United States (Announcements, 2003; Mackey, 2005). Although the older elementary and high school cohorts are, by far, the best supplied age groups, both for general nonfiction and particularly for reference books, there are hundreds of non-fiction titles published each year in the United States aimed at early readers (Palmer and Stewart, 2003). However, since curricular need and profitability tend to drive much of the market, the range of topics may be too narrow to appeal to the wide range of young children's interests.

In summary, then, research suggests that exposure to information books as well as fiction has a beneficial effect on the reading lives of young children, and the publishing industry produces a reasonable range of materials aimed at this cohort. 


\section{Are these books accessible to emergent readers?}

Small children have little opportunity to find reading materials on their own, and may be unaware of the range of books written for them. It is therefore up to the parents, teachers and librarians in the child's life to provide materials the child may benefit from using. This access is in a variety of ways: through school classrooms and libraries, retail purchases, and public libraries. However, my search for information about availability showed that little research has been done on this topic, and therefore a comprehensive assessment of access is missing. The few relevant studies I found point to limited access across some venues.

\section{Information books in the school setting}

\section{The school classroom}

The classroom is a particularly important source of reading materials for students of all ages; it is here the child has the opportunity to find books used both for curricular requirements and home reading programs, and for voluntary reading. For some children, these collections may be their only exposure to books because they do not visit the public library and have no money to buy materials (Worthy, 1996; Krashen, 2002). In response to the call for more exposure to information texts in the primary classroom for both curricular and interest reasons, there has been initial research to assess the availability of these texts for beginning readers. While studies are few, they suggest trends in access.

Series books, or basal readers, often make up a large proportion of the introductory reading materials in the early elementary classroom; Moss and Newton (2002) noted that 95 percent of classrooms in the United States use these series.

However, past studies have noted that there are few informational books included in these sets. Hoffman et al. (1994) found an average of $12 \%$ of books in five basal series aimed for Grade 1 were non-fiction, while Moss and Newton cited 16\% non-fiction selections in six Grade 2 level basal reading series. These studies predate some of the work that has promoted non-fiction for emergent readers. A quick perusal of a few series books available today (Alberta Learning, 2004b) suggested that some series have a balanced selection of both fiction and non-fiction, while others are predominantly fiction. Further study of series books to assess changes in response to the recent focus on non-fiction 
books would be useful; however, what is more to the point is what is actually used in the classroom.

Research suggests that texts teachers present to the class are also largely narrative. Pressley, Rankin and Yokoi (1996), in a study of Kindergarten, Grade 1 and Grade 2 teachers across the United States recommended as having strong literacy programs, found that on average only $6 \%$ of what was read was expository. Yopp and Yopp (2000) interviewed 126 primary school teachers and found only $14 \%$ of materials read aloud were informational in nature. Duke (2000) set about to quantify the presence of informational texts in twenty first grade Boston area classrooms by an analysis of informational textual elements such as books, posters, written language activities, and classroom library titles. Her results showed "a scarcity of informational texts in these environments and activities" (Duke, p.203); only 3.6 minutes per day, on average, was spent with informational texts in classroom written activities.

There have been numerous books and articles suggesting ways to integrate nonfiction into the primary literacy curriculum (e.g. Duthie, 1994; Guillaume, 1998; Jobe and Dayton-Sakari, 2002; Bamford and Kristo, 2003; Moss, 1995, 2003, 2004a,b; Livingston et al., 2004; Stien and Beed, 2004; Palmer and Stewart, 2005; Soalt, 2005); new research studies of what is used in the classroom would be useful to ascertain whether these past trends are still prevalent.

The classroom book collection, if present, is another potential source of nonfiction for young readers, especially for voluntary reading. But again, studies that have looked at these collections have found a dearth of non-fiction. Fractor, Woodruff, Martinez and Teale (1993) in a study of 183 classrooms in a metropolitan district of Texas found that $72 \%$ of Kindergarten rooms and $55 \%$ of Grade 1 classes had classroom libraries. Duke's (2000) data of Grade 1 classrooms in Boston found few informational books in the classroom book collection. Palmer and Stewart's study (2003) of first grade classrooms in the northwest United States found that the information books in the classroom were often too difficult for the children to read; while more complex books with pictures are a favourite for children, they do not provide the skill-appropriate reading experience. Palmer and Stewart stated that this lack of age appropriate books 


\section{Language and Literacy}

occurred because the teachers and library staff were unaware of what was available for this age group and so resorted to whatever they could find.

In summary, the relative presence of non-fiction in the early elementary classroom has not been confirmed in other school jurisdictions and is a subject for further research; certainly results may vary widely from classroom to classroom, and some may use information texts often (e.g. Richgels, 2002). However, considering the aforesaid past preference for stories in both teaching methods and materials, it is possible that the trend of making little use of non-fiction is widespread.

\section{The school library}

The school library plays a central role in young children's reading lives, by providing them with both curricular and free reading materials, and by introducing children to what the library can do for them. For some, this may be the first and sole library experience. There is a significant body of literature supporting the role of the school library, the presence of a teacher-librarian, and the size of the collection in student reading ability and academic achievement across a range of subjects (see Haycock, 2003, for review; Krashen, 2004; Lance and Loertscher, 2003). Materials for voluntary reading are particularly important for sustaining interest in reading; students' decision to read or not to read is often dependent on whether or not they can find what they like to read (Worthy, 1996). The role of the school library and its staff in promoting this voluntary reading through provision of good advice and a varied collection is pivotal (Haycock). Haycock, in his review calling for renewed investment in school libraries in Canada, noted that "one can safely conclude that there is ample evidence of the school library's importance as an academic investment" (p. 21) and that "school libraries must be the centre of any plan to improve reading and literacy" (p. 19).

Although the importance of the school library for beginning readers is evident, research specifically into the quality of selection of emergent readers' information books in school libraries is lacking. However, the few available studies into related aspects of school library budgeting and collections are noteworthy, and may indicate trends relevant to this cohort.

Funding, or lack thereof, is a crucial issue in the quality of collections in school libraries in Canada (Haycock, 2003). A recent Statistics Canada report states that school 
libraries in Canada are poorly funded and have little money to spend on materials (Statistics Canada, 2005; Schmidt, 2005; Coish, 2005). For information books, curricular need is the first priority for purchases (Worthy, Turner and Moorman, 1998), and in times of financial restraint there is little money for the essential materials, let alone recreational reading titles. Additionally, in schools that must provide for several different streams of curriculum such as wide age ranges, second languages, and so on, budgets are stretched very thinly for each area. Coupled with this is the fact that non-fiction books can become outdated very quickly. Therefore the school library may fall short in its ability to provide a wide range of information titles to accommodate the array of student need and interest.

In times of financial restraint, the relative usefulness of early readers' information books may also play a role in compromising access. An information book aimed at a ten year old may be of use to students several years younger as well as several years older. However, a book aimed at a six year old may only be chosen by children younger than about eight years or so. As information resources, these books therefore tend to be seen as a poor choice for scant funds because children outgrow them so quickly, and because children often seem to be satisfied with looking at pictures in more complex non-fiction books. Therefore in times of budget constraint it makes more practical sense to buy materials with the broadest usage. This may be short term economy, however, as the long term benefits of improving reading skills for the younger cohort may not be fully appreciated. As well, a shortage of these books is a particular loss for those students who are reading below grade level and prefer non-fiction to fiction.

Worthy, Moorman and Turner's study of Grade 6 students in Texas (1999) also sheds light on the aspect of choice in selection of school library materials. They noted there was a discrepancy between what students liked to read and what was available; while favourite materials were magazines, scary stories and cartoon books, some of the students interviewed enjoyed books about sports, cars, animals and the like, but all these materials were in short supply. This is particularly unfortunate as these non-fiction books are often preferred by reluctant readers (Jobe and Dayton-Sakari, 2002). Lack of money, inappropriateness of the requested material, and a reluctance to provide what is seen as light reading material when there were more pressing curricular concerns were cited by teachers and school librarians as some of the reasons for this inadequacy. While this 
study focussed on older readers, it is possible that the same shortfall exists for all ages. Guidelines such as the Province of British Columbia's Developing independent learners: The role of the school library resource centre (1991), and Alberta's Focus on Learning: An integrated program model for Alberta school libraries (1985), do not give specific guidelines for collection content, and since choices for collections are made at the school level, collection quality may vary from school to school and for each age group.

Library design may also be a factor in access. While much time is spent making the library an appealing place to encourage reading (e.g. Kruise, 1992; Doll, 1992; Beers, 1996b; Berg, 1984), my background study of public libraries (Larkin-Lieffers, 2001) suggests that shelving types and prime locations near the tables or high traffic areas favour fiction, and it is possible that the same situation arises in school libraries as well, on a smaller scale. Preference for genre in displays and in read-alouds to primary students may also be similar to those preferences found in the kindergarten and primary classrooms discussed previously.

Given the importance of information books for emergent readers, and the pivotal role of the school library in introducing young children to these materials, more comprehensive research assessing collection strength, and factors which influence access, would be timely.

In summary, then, the scant research into the presence of information books in the school life of emergent readers suggests that access may not be optimum. Preference for narrative in the classroom may be an ongoing issue for reasons that have not been clearly understood. The strength of the collections of beginning information books in school libraries has not been ascertained, but budget restraints do not suggest a happy assessment. Further research into this area may help to clarify the present situation in both classrooms and libraries, and point direction for improvement.

\section{Retail outlets for books}

For those young children and parents fortunate enough to have sufficient funds, retailers offer another venue for information books. A Publishers Weekly and BookExpo survey of 400 American adults to examine consumer trends in book buying for children (Ferguson, 1998) provides a glimpse of this market. The study found that adults typically buy books for children because they see them as important in a child's development. 
Consumers are predominately women (62\%), well educated, and with above average incomes. They generally buy more books for boys (55\%) than girls (45\%). Because they like the books to last, $60 \%$ of the interviewees said they bought hardcover books for children under the age of six. Fiction was a strong preference; $72 \%$ chose fiction titles compared to just $28 \%$ non-fiction. Bookstore chains (45\%), followed by mass merchandise stores $(21 \%)$, independent bookstores $(10 \%)$, and book fairs $(7 \%)$ were the preferred places to shop (Ferguson). A more recent study lists book clubs and fairs, usually operating through schools, as accounting for $26 \%$ of children's books sold in 2002 (Raugust, 2002), indicating ongoing shifts in markets. The Internet is also a venue for book sales.

I visited seven stores in a western Canadian city: two chain bookstores, two independent bookstores, and three mass merchandise stores that carried books as a sideline to other merchandise (toys, groceries and household merchandise) to assess local availability of information books for emergent readers. Generally, selection of fiction books for all age groups was significantly better than that for information books. The largest chain bookstore, for example, had 43 shelf panels devoted to children's fiction, and only seven for children's reference and non-fiction. The independent stores were slightly better balanced but fiction still predominated. In the four bookstores I visited, fiction and non-fiction were shelved separately, and fiction tended to be shelved by age groups, such as birth to two years, three to five, six to eight, nine to twelve, and so on. Non-fiction, however, was all grouped together. Only the largest chain bookstore had any age division for the non-fiction, and this was for nine to twelve years only even though there were a few books on the shelves aimed at younger children. Information books for any age tended to be divided by subject, but these were generally limited to animals, space, things that go, dinosaurs, life issues such as divorce, television shows, and the like. Surprisingly, no sports categories were found. In stores that carried books as a sideline to other merchandise, there were no significant divisions of materials and selection for both genres was limited, with non-fiction including mostly concept books, sticker books with a variety of themes such as animals, trucks, knights, Egypt, and other historical topics, and a few animal and truck books. 
The selection of information books specifically for emergent readers in all the stores visited, and for all topics, was small, and limited mostly to paperback books and sticker books, and a few hardcover activity information books. In the largest chain bookstore, the most popular consumer choice for purchasing children's books, (Ferguson, 1998), less than ten per cent of the books available for ages three to eight were nonfiction. Interestingly, there was a better selection of information books for birth to two years; these tended to be animal, truck, and concept board books. The independent bookstores tended to carry some non-fiction hardcover titles, but again most of the choice was paperback. Early reader levelled series paperback books such as I Can Read titles were present in considerable quantity in the bookstores; these often had a better representation of non-fiction books, up to twenty-five percent. But again, the large majority of these titles were stories, and there was no division of stories and information books in the shelving.

A perusal of a book club holiday gift buying pamphlet showed that approximately one-third of the books aimed for children five to eight were non-fiction.

\section{Identifying quality in purchasing books: Book awards}

One reason for the limited selection of information books in retail stores may be a lack of book awards highlighting this genre. Award winners are recognizable by their promotional stickers and posters, and are often given preferential shelving locations.

Children's literature awards and prizes focused, until the 1970s, almost exclusively on fiction; however, recognition for quality of non-fiction books has increased with the rise in numbers of informational books published in the last three or four decades (Giblin, 2000). Several awards have been established to honour non-fiction works for children, including the Boston Globe-Horn Book Award for Non-fiction (1976) (Boston Globe-Horn Book Awards, 2005), the Golden Kite Award (1973) (Society of Children's Book Writers and Illustrators, 2005), the Orbis Pictus Award (1990) (Vardell, 1991), Washington Post-Children's Book Guild Award (1977) (The Children's Book Guild of Washington, D.C., 2005), the Sibert Informational Book Medal (2001) (American Library Association, 2005), and the Outstanding Science Trade Books for Children Award (1973) (National Science Teachers Association, 2005), in the United States. Australia awards the Eve Pownall Award for Information Books (Christchurch 
City Libraries, 2005), and Canada lists the Information Book Award, Norma Fleck Award for Children's Non-fiction, Science in Society Book Award, and Canadian Science Writer's Award (Canadian Children's Book Centre, 2005). Many prestigious awards can be given for either fiction or non-fiction; however, the numbers given for fiction outnumber by several factors those allotted to non-fiction. The Newbery Award, for example, listed only one non-fiction book as an Honor book in the 1970s, cited three for Honor recognition in the 1980s, and awarded the Medal for Lincoln, a Photobiography, by Russell Freedman, in 1988. This was the first medal for this genre since 1956 (Giblin, 2000). Three books were awarded Honor status in the 1990s (Giblin) and two to date in this decade. The Dr. Seuss Award (2006) will recognize a significant contribution to beginning readers' books (American Library Association, Association for Library Service to Children, 2005). While more recognition has come to children's nonfiction, the number of awards given for this genre is far outnumbered by the awards given for children's fiction (Children's Literature, Awards and Prizes, 2004). Recognition of information books for the very young is particularly rare.

My local survey of retail stores' stocks of non-fiction books for the emergent reader show that these books are not readily available to consumers, despite the large numbers published. While these results may not be representative of all stores, it is likely that this situation is widespread, given that the wholesale buying for chain bookstores and chain merchandisers is usually centrally dictated. Customers tend to choose fiction; whether or not the small selection of information books is a cause of this preference, or if the small selection is a reaction to customer choice, is unknown. Further research into consumer awareness of products, reasons for customer choices for young children, purchasing preferences online, and marketing strategies to educational and retail points of sale and the products they highlight may shed light on this aspect of access.

\section{Information books in the public library}

The public library has been a leader in the provision of materials for young children, and the importance of the library as a source of information books for young readers has been particularly significant given the past lack of availability of these materials in other locations. Public libraries offer a variety of opportunities for children to find information books, through their collection, book talks (Baxter, 1997), reading 
clubs, displays, posters and so on. One of the more important features of the public library is that it offers a wide range of materials that are not dictated by curriculum, and therefore young children have the opportunity to browse, and to widen interest (Canon, 1988). Scheps (1991) made the point that since fiction tends to be more widely used in the classroom, children may look only for fiction in the library for their recreational reading. The public library therefore has the opportunity to introduce them to non-fiction so that they are aware of the full range of books available for them. This element of choice encourages reading (Ross, 2001). Additionally, the opportunity to choose and reject books without penalty helps children to hone their selection skills; Timion (1992) noted that her first-graders felt that the most difficult part of learning to read was choosing the right book. Krashen (2004) pointed out that libraries provide "access to books and a quiet comfortable place to read" (p. 63), crucial elements that encourage reading and that may be missing in many children's lives. Positive experiences in the library set the stage for continued interest in reading, and the public library thus is pivotal in fostering early literacy en route to a lifetime of reading.

As with school libraries, budget constraints may play a major role in the collection size of information books for the very young. If money is scant, collections tend to favour non-fiction aimed at older children because these books have a wider readership which can include children of all ages as well as adults (B. Dimond, personal communication, April 3, 2005). Other program needs such as books in other languages, seniors' materials and adult literacy books also must be accommodated in the budgeting (Maxwell, 1993). No surveys of the relative presence of non-fiction books for the emergent reader in public libraries in Canada could be found, therefore there is no indication of how well these materials are represented in children's public library collections.

When the public library does carry a variety of information books for this cohort, research suggests that in some libraries they are not easily accessible for young children and their parents. There are several contributing factors to this compromised access. My background study of ten branch public libraries (Larkin-Lieffers, 2001) showed that the shelf height and shelving type for young children's books often favour fiction. The preferred eye level and below eye level (Reutzel and Gali, 1998; Larkin-Lieffers), 
facefront (Langhorne, 1987; Charlton, 1989; Long, 1987) shelving in most children's areas is used for picture storybooks and the smaller collections of paperback fiction and non-fiction, while the hardcover information books are shelved spine out, often in tall shelving out of reach of young children. Location is also important in that books that are located in prime locations generally circulate more than those farther away (Baker, 1986; Shaw, 1938; Langhorne). In the study libraries, the picture storybook shelves were located around the children's tables where the caregivers often preferred to sit and supervise their children (Larkin-Lieffers), while the hardcover non-fiction shelves were farther away from the tables and picture books, or located in the adult non-fiction section. While Reutzel and Gali (1998) suggested that young children can find their way in the stacks, Eaton's work on spatial ability (1991), Shenton and Dixon's study (2004) of children's public library non-fiction search strategies, and my observations of young children in the libraries suggest limited physical search skills. Young children seldom wander far from their caregiver, but prefer to sit on the floor and read whatever is closest, or choose materials that are close by (Larkin-Lieffers). Therefore this shelving arrangement essentially eliminates the possibility for the child to find age appropriate information books other than the relatively small collection of paperback information books. The Easy Read books were sometimes in a more accessible location; however, these collections are often heavily weighted to fiction. The type and location of shelving, and the location of the children's furniture, then, have a significant effect on access to information books for emergent readers.

Displays and posters are useful for advertising the variety of books in the library (Goldhor, 1972, 1981; Baker, 1986; Berg, 1984), especially for young children who are more dependent on visual cues to find books (Watson, Clayburn and Snider, 1985). Dalton (1990) noted that children will choose familiar books from the stacks but will try new books that look interesting if they are displayed. However, in my study libraries (Larkin-Lieffers, 2001) fiction titles made up most of the shelf-top displays. As well, libraries often highlight award winning books, and since these are predominantly fiction, non-fiction again remains the less displayed genre.

Librarians can also introduce children to various genres through book talks at schools, time for two programs or preschool story-time, and the like. Young children's 
enjoyment of information books for read-alouds has been noted in several articles (e.g. Pappas, 1993; Putnam, 1991; Baxter, 1997). Timion (1992) noted that children will often choose a book to read because they have heard it read to them while Krashen (2004) remarked that children who are read to, will read more. No quantification of information versus fiction materials presented in these library read-alouds has been done to assess whether information books are given reasonable exposure.

One modification to the children's areas in recent years has been to provide a catalogue aimed at children's cognitive abilities. However these catalogues are too advanced for emergent readers because they require a minimum literacy competence and an understanding of classification schemes that is over their heads cognitively (Sandlian, 1995). Kuhlthau (1988) noted that children begin to understand that books have some sort of classified arrangement only by about age seven, but do not understand how the basic Dewey arrangement works until age nine, with more detailed understanding as they learn decimals. A child sized reference desk in the children's area is also helpful in theory, but some children find asking questions too frightening (Dixon, 1996) and they rarely ask (Sandlian). A troubling finding by some researchers of older children's search methods is that when they do ask, boys ask fewer questions than girls (Bennett, 1998; Burdick, 1996), and these are often the young children who are most interested in nonfiction.

The role of the parents and caregivers in choosing or helping their children to choose books should not be underestimated. The adults choose when to go to the library, decide where to sit, and often make book choices for the child or monitor what the child is allowed to take home (Larkin-Lieffers, 2001). Shenton and Dixon (2004) noted that the young children searching for non-fiction books in two English public libraries were wholly dependent on the accompanying adults for help. My public library study showed that the parents observed did not search far away from where they set themselves as the home base for the library visit, usually at the children's tables. None were observed asking for help from the librarians (Larkin-Lieffers), a common reaction to reference service (Swope and Katzer, 1972). Some children's areas have online catalogues, but while their location in the children's area may provide easier access for caregivers, many adults are not familiar with online catalogue use (Thorne and Whitlatch, 1994; Borgman, 
1996) or cannot find the requested books (Thorne and Whitlatch; Mellon, 1986). As well, caregivers often come with more than one child and may be fully occupied with their supervision. Reutzel and Gali's study (1998) of children's book selection showed that children who are rushed to choose a book, for instance as the parent is leaving, will often pick one at random, which may be a disappointing choice. If restricted in the numbers of books they can take out, they may choose ones that are long, rather than interesting, because "it has to last ... for a whole week" (Reutzel and Gali, p. 37). As well, parents may have their own expectations for what is appropriate reading material. The behaviour of the accompanying adults, then, can significantly affect their children's success at finding the materials they want. In some libraries, small children may come unaccompanied or with a sibling; Neuman (2002) noted that these children tend to have scattered focus and "brief glancings of books" (p. 75) along with undirected activity. How successful they are in finding information books, and what they choose, is unknown.

In summary, then, the public library has an opportunity to provide emergent readers with an array of age appropriate information books through their collection, book talks, displays and the like. However, budget constraints, library design, and preferences for displays and read-alouds may compromise this access. The role of the parents and caregivers may also be significant in the choices made.

\section{If information books are so important, why can't young children find them?}

Despite the evidence that emergent readers enjoy and benefit from opportunities to read information books aimed at their reading and intellectual level, and numbers that indicate that publishers are providing a reasonable selection for this age group, the conclusion from this preliminary overview of access is that emergent readers are not being given sufficient opportunity to choose these books. Few studies have looked at the accessibility of these books, and the ones that do, suggest limited access. In the primary school classroom, studies note that fiction predominates in the classroom; however, there are indications that some new series books may include more non-fiction, and there are numerous books and articles on how to integrate non-fiction into early literacy. The question is whether these initiatives are being implemented. In school libraries, no assessment of collections of these books has been done, but budget constraints do not 
suggest strong representation. What is chosen may not be what children are interested in reading, while library design, such as types and locations of non-fiction shelving, may also play a role in compromising access. Preference for fiction in displays and readalouds may also be an issue, though this has not been ascertained. Bookstores strongly prefer fiction to non-fiction in what is offered for sale; whether this is determined by the bookseller or the book buyer is unknown. Finally, in public libraries, no assessment of collection strength has been conducted, but budget constraints may reduce collection size. When collections do offer a good variety, aspects of library design, such as types and locations of shelving, favour fiction. Displays are also mostly fiction. Parental input may also influence access.

Clearly, we need to know more about the level of access, and the reasons for any compromised access, in order to improve young children's opportunities to find age appropriate information books. In this way, strategies can be developed to provide the best support for young children as they learn to read, which is the goal of any literacy initiative.

\section{Acknowledgements}

The author would like to thank Dr. Margaret Mackey for her advice on reading issues, editorial comments, and generous support throughout the evolution of this study. Kathleen Larkin provided valuable insight on a range of topics concerning both public and school libraries while Beth Dimond clarified points concerning public library children's non-fiction collections. Jackie Martin was always ready to discuss school library issues with me. Their contributions to this paper are gratefully recognized.

\section{References}

Adams, M.J. 1990. Beginning to read: Thinking and learning about print. Cambridge, Massachusetts: MIT Press.

Alberta Education, Media and Technology Branch. 1985. Focus on learning: An integrated program model for Alberta school libraries. Edmonton: Alberta Education, Media and Technology Branch. 
Alberta Learning. 2004a. Curriculum handbook for parents, 2004-2005: Grade 1.

Edmonton, Alberta: Alberta Learning. Accessed online at http://www.education.gov.ab.ca/parents/handbooks/pub1.pdf, April 18, 2005.

Alberta Learning. 2004b. Alberta authorized resource list kindergarten to grade 3 (primary programs): Early literacy, early numeracy, integration, diagnostic assessment. Edmonton, Alberta: Alberta Learning. Accessed online at http://www.education.gov.ab.ca/k_12/curriculum/bySubject/kto3.pdf, April 18, 2005.

Allington, R.L. 1994. The schools we have. The schools we need. The Reading Teacher, 48(1), 14-29.

American Library Association, Association for Library Service to Children, Theodor Seuss Geisel Award. 2005. Accessed online at http://www.ala.org/ala/alsc/awardsscholarships/literaryawds/drseussaward/DrSeus sAward.htm, May 10, 2005.

American Library Association, Robert F. Sibert Informational Book Medal. 2005. Accessed online at http://staging.ala.org/Template.cfm?Section=bookmediaawards\&template=/Conte ntManagement/ContentDisplay.cfm\&ContentID=21608, May 10, 2005.

Announcements: Spring children's books. 2003. Quill and Quire, 69(4), 19-31

Bainbridge, J., and Malicky, G. 2002. Constructing meaning: Balancing elementary language arts $\left(2^{\text {nd }}\right.$ ed.). Scarborough, Ontario: Nelson Thompson Learning. 
Baker, S. 1986. The display phenomenon: An exploration into factors causing the increased circulation of displayed books. Library Quarterly, 56(3), 237-257.

Bamford, R.A., and Kristo, J.V. 2003. Making facts come alive: Choosing and using quality nonfiction literature K-8. Norwood, Mass.: Christopher-Gordon.

Baxter, K. 1997. Unbeatable booktalks: Try talking nonfiction; kids (and you) will find it irresistible. School Library Journal, 43(3), 121.

Beer, S. 2004a. Facing the facts. Bookseller, 8/20/2004 Supplement, p. 17, 2pp.

Beer, S. 2004b. Selling the facts. Bookseller, 8/20/2004 Supplement, p. 18, 2pp.

Beers, G. K. 1996a. No time, no interest, no way! The three voices of aliteracy. Part 1. School Library Journal, 42(2), 30-33.

Beers, G. K. 1996b. No time, no interest, no way! The three voices of aliteracy. Part 2. School Library Journal, 42(3), 110-113.

Bennett, B.A. 1998. Gender questions: Asking for directions on the information highway. Knowledge Quest, 27(2), 24-25.

Berg, J. 1984. Encouraging choice: A resource teacher outlines some of the imaginative ways she encourages children to become aware of the variety and richness of the materials in a school library. Australian Journal of Reading, 7(4), 205-209.

Borgman, C. 1996. Why are online catalogs still hard to use? Journal of the American Society for Information Science, 47(7), 493-503.

Boston Globe-Horn Book Awards. 2005. Accessed online at http://www.hbook.com/awards/bghb/past.asp, May 10, 2005.

Burdick, T.A. 1996. Success and diversity in information seeking: Gender and the information search styles model. School Library Media Quarterly, 25(1), 19-26. 
Language and Literacy

Canadian Children's Book Centre Canadian Awards Index. 2005. Accessed online at http://www.bookcentre.ca/awards/award ind/index.shtml, May 10, 2005.

Canon, M.J. 1988. No more dinosaurs, please! School Library Journal, 34(10), 56.

Caswell, L. J., and Duke, N. K. 1998. Non-narrative as a catalyst for literacy development. Language Arts, 75(2), 108-117.

Charlton, J. 1989. How to judge a book by its cover: The child's guide for adults choosing books for children. Emergency Librarian, 17(2), 30-31.

Children's Literature, Awards and Prizes. 2004. Accessed online at http://www.childrenslit.com/award link.html, October 6, 2005.

Childress, G.T. 1985. Gender gap in the library: Different choices for girls and boys. Top of the News, 42, 69-73.

Christchurch City Libraries. Children's Book Council of Australia Awards. 2005. Accessed online at http://library.christchurch.org.nz/childrens/literaryprizes/childrensbookcouncil/ev epownall/, May 10, 2005.

Coish, D. 2005. Canadian school libraries and teacher-librarians: Results from the 2003/04 technology and communications technologies in schools survey. Ottawa: Ministry of Industry, Statistics Canada. Accessed online at http://www.statcan.ca/cgi-bin/downpub/listpub.cgi?catno=81-595-MIE2005028, October 5, 2005.

Dalton, P. 1990. An exploration of the value of creating book displays in a school media center, Fall 1990. ED 340380. 
Dayton-Sakari, M., and Jobe, R. 2003. Reluctant readers choose nonfiction: Just give me the facts! Bookbird, 41(1), 21-27.

Dixon, J. 1996. Are we childproofing our libraries? Identifying the barriers that limit library use by children. Public Libraries, 35(1), 50-56.

DK Publishing Inc. 2006. dk.com. Company overview. Accessed online at http://us.dk.com/static/cs/us/11/about/company.html, July 14, 2006.

Doiron, R. 2003. Motivating the lifelong reading habit through a balanced use of children's information books. School Libraries Worldwide, 9(1), 39-49.

Doll, C.A. 1992. School library media centers: The human environment. School Library Media Quarterly, 20, 225-230.

Dreher, M. J. 2003. Motivating struggling readers by tapping the potential of information books. Reading and Writing Quarterly, 19, 25-38.

Duke, N. K. 2000. 3.6 minutes per day: the scarcity of informational texts in first grade. Reading Research Quarterly, 35(2), 202-224.

Duke, N. K. 2004. The case for informational text: Younger students need to expand their repertoire and build literacy skills with informational text. Educational Leadership, 61(6), 40-44.

Duke, N.K., and Kays, J. 1998. “Can I say 'Once upon a time’?”: Kindergarten children developing knowledge of information book language. Early Childhood Research Quarterly, 13(2), 295-318.

Duthie, C. 1994. Nonfiction: A genre study for the primary classroom. Language Arts, $71,588-595$. 
Eaton, G. 1991. Lost in the library: Are spatial skills important in shelf searches? Journal of Library Services in Libraries, 5(1), 77-86.

Egan, K. 1988. Primary understanding: Education in early childhood. New York: Routledge.

Elleman, B. 1998. To market to market: A look at children's book publishing. School Library Journal, 44(4), 44-45.

Engelhardt, T. 1991. Reading may be harmful to your kids: In the Nadirland of today's children's books. Harper's Magazine, 282(1693), June 1991, 55-62.

Ferguson, A. 1998. Reading seen as “cool”: Survey of children's book market offers good news to publishers and booksellers. Publishers Weekly, 245(41), 28-31.

Fink, R. P. 1995. Successful dyslexics: A constructionist study of passionate interest reading. Journal of Adolescent and Adult Literacy, 39(4), 268-280.

Fisher, R. 2004. Curiosity kits: Linking reading and play in the middle years. In J. Evans (Ed.), Literacy moves on: Using popular culture, new technologies and critical literacy in the primary classroom (pp. 134-144). London: David Fulton.

Fractor, J.S., Woodruff, M.C., Martinez, M.G., and Teale, W.H. 1993. Let's not miss opportunities to promote voluntary reading: Classroom libraries in the elementary school. Reading Teacher, 46(4), 476-484.

Freeman, E. B. 2003. Informational books in the United States. Transitions and trends. Bookbird, 41(1), 6-13.

Giblin, J. C. 2000. More than just the facts: A hundred years of children's nonfiction. Horn Book, 76(4), 413-424. 
Goldenberg, C. 1992. An interview with Peter Kindersley. Horn Book Magazine, 68(3), 297-308.

Goldhor, H. 1972. The effect of prime display location on public library circulation of selected adult titles. Library Quarterly, 42(4), 371-389.

Goldhor, H. 1981. Experimental effects on the choice of books borrowed by public library adult patrons. Library Quarterly, 51(3), 253-268.

Guillaume, A.M. 1998. Learning with text in the primary grades. The Reading Teacher, $51(6), 476-486$.

Hade, D. 2002. Storyselling: Are publishers changing the way children read? Horn Book Magazine, 78(5), 509-517.

Hartlage-Striby, K. 2001. Girls choose fiction; boys choose non-fiction. Kentucky Libraries, 65(4), 36-40.

Haycock, K. 2003. The crisis in Canada's school libraries: The case for reform and reinvestment. Toronto: Association of Canadian Publishers.

Hepler, S. 2003. Nonfiction books for children: New directions, new challenges. In R.A. Bamford and J. V. Kristo (Eds.), Making facts come alive: Choosing and using quality nonfiction literature K-8 (pp. 3-20). Norwood, Massachusetts: Christopher-Gordon.

Hidi, S.E., and Hildyard, A. 1983. The comparison of oral and written productions in two discourse types. Discourse Processes, 6, 91-105.

Hoffman, J.V., McCarthey, S.J., Abbott, J., Christian, C., Corman, L., Curry, C., Dressman, M., Elliott, B., Matherne, D., and Stahle, D. 1994. So what's new in the new basals? A focus on first grade. Journal of Reading Behavior, 26, 47-73. 
Jobe, R., and Dayton-Sakari, M. 1999. Reluctant readers: Connecting students and books for successful reading experiences. Markham, Ontario: Pembroke Publishers.

Jobe, R., and Dayton-Sakari, M. 2002. Info-kids: How to use nonfiction to turn reluctant readers into enthusiastic learners. Markham, ON: Pembroke.

Krashen, S. 2002. What do we know about libraries and reading achievement? Book Report, 20(4), 38 .

Krashen, S. 2004. The power of reading: Insights from the research ( $\left.2^{\text {nd }} \mathrm{ed}.\right)$. Westport, CT: Libraries Unlimited.

Kruise, C.S. 1992. Welcoming new kindergarteners. School Library Journal, 38(12), 40.

Kuhlthau, C.C. 1988. Meeting the information needs of children and young adults: Basing library media programs on developmental states. Journal of Youth Services in Libraries, 2(1), 51-57.

Lance, K.C., and Loertscher, D.V. 2001. Powering achievement: School library media programs make a difference: The evidence. San Jose, CA: Hi Willow.

Langer, J.A. 1985. The child's sense of genre: A study of performance on parallel reading and writing tasks. Written Communication, 2(2), 157-187.

Langhorne, M. 1987. Marketing books in the school library. School Library Journal, $33(5), 31-33$.

Larkin-Lieffers, P. A. 2001. Informational picture books in the library: Do young children find them? Public Library Quarterly, 20(3), 3-28. 
Leal, D. 1993. Storybooks, information books and informational storybooks: An explication of the ambiguous grey genre. New Advocate, 6(1), 61-70.

Lempke, S. D. 2003. Summing it up in 24 pages: Nonfiction series for the young. Booklist, 100(4), 436.

Levy, S. 2002. Don't dumb them down: A new study by an expert on web design shows what's wrong - and even dangerous - about kids' sites. Newsweek, 139(16), 56.

Livingston, N., Kurkjian, C., Young, T., and Pringle, L. 2004. Nonfiction as literature: An untapped goldmine. The Reading Teacher, 57(6), 582-584.

Long, S. 1987. The effect of face-front book display in a public library. North Carolina Libraries, 45(3), 150-153.

Mackey, M. 2005. Canadian young people and their reading worlds: Conditions of literature in contemporary Canada. CCL/LCJ: Canadian Children's Literature/Littérature canadienne pour la jeunesse, 31(1), 78-99.

Maxwell, E. 1993. The planning and design of children's libraries. Library Management, 14(7), 23-35.

McKechnie, L.E.F. 2004. "I'll keep them for my children" (Kevin, nine years): Children's personal collections of books and other media. The Canadian Journal of Information and Library Science, 28(4), 73-88.

Meek, M. 1996. Information and book learning. Stroud, Glos: Thimble Press.

Mellon, C. 1986. Library anxiety: A grounded theory and its development. College and Research Libraries, 47, 160-165.

Moore, 2003. Choosing quality nonfiction literature: Aspects of selection for emergent, early, and transitional readers. In R.A. Bamford and J. V. Kristo (Eds.), Making 
Language and Literacy

facts come alive: Choosing and using quality nonfiction literature K-8 (pp. 97-

118). Norwood, Massachusetts: Christopher-Gordon.

Moss, B. 1995. Using children's nonfiction tradebooks as read-alouds. Language Arts, $72(2), 122-126$.

Moss, B. 2003. Exploring the literature of fact: Children's nonfiction trade books in the elementary classroom. New York: Guildford.

Moss, B. 2004a. Teaching expository test structures through information trade book retellings. The Reading Teacher, 57(8), 710-718.

Moss, B. 2004b. Fabulous, fascinating FACT BOOKS. Instructor (1999), 113(8), 28. $3 p p$.

Moss, B., and Newton, E. 2002. An examination of the informational text genre in basal readers. Reading Psychology, 23: 1-13.

National Science Teachers Association. 2005. Accessed online at http://www.nsta.org/ostbc, May 10, 2005.

Neuman, S. 2002. The role of school libraries in elementary and secondary education. Teacher Librarian, 30(1), 74-75.

Palmer, R.G. and Stewart, R. A. 2003. Non-fiction trade book use in primary grades. The Reading Teacher, 57(1), 38-48.

Palmer, R.G. and Stewart, R.A. 2005. Models for using nonfiction in the primary grades. The Reading Teacher, 58(5), 416-434.

Pappas, C. C. 1991. Fostering full access to literacy by including information books. Language Arts, 68, 449-462. 
Pappas, C. C. 1993. Is narrative "primary"? Some insights from kindergartners' pretend readings of stories and information books. Journal of Reading Behavior, 25(1), 97-129.

Pressley, M., Rankin, J., and Yokoi, L. 1996. A survey of instructional practices of primary teachers nominated as effective in promoting literacy. Elementary School Journal, 96, 363-384.

Province of British Columbia, Ministry of Education, Learning Resources Branch. 1991. Developing independent learners: The role of the school library resource centre. Victoria, British Columbia: Ministry of Education.

Putnam, L. 1991. Dramatizing nonfiction with emerging readers. Language Arts, 68, 463-469.

Raugust, K. 2002. Back to school: Educational marketing activities spur sales. Publishers Weekly, 249(50), 30-31.

Reutzel, D.R. and Gali, K. 1998. The art of children's book selection: A labyrinth unexplored. Reading Psychology: An International Quarterly, 19, 3-50.

Richgels, D. J. 2002. Informational texts in kindergarten. The Reading Teacher, 55(6), $586-595$.

Rodgers, M.M. 2003. Publishing children's nonfiction. Bookbird, 41(1), 37-38.

Rosenblatt, L. M. 1991. Literature - S.O.S.! Language Arts, 68, 444-448.

Ross, C.S. 1995. 'So they read Nancy Drew, so what?' Series book readers talk back. Library and Information Science Research, 17(3), 201-236. 
Ross, C.S. 2001. Making choices: What readers say about choosing books to read for pleasure. In B. Katz (Ed.), Readers, reading and librarians (pp. 5-21). New York: Haworth Information Press.

Sanacore, J. 1991. Expository and narrative text: Balancing young children's reading experiences. Childhood Education, 67(4), 211-214.

Sandlian, P. 1995. Rethinking the rules. School Library Journal, 41(7), 22-25.

Scheps, S. 1991. Whole language in the public library: Same as it ever was. School Library Journal, 37(7), 26-27.

Schmidt, S. 2005. School libraries starving for books, librarians report finds. Canada.com News, Thursday May 5, 2005. Accessed online at www.canada.com, May 6, 2005.

Shaw, R. 1938. The influence of sloping shelves on book circulation. Library Quarterly, 8(4), 480-490.

Shenton, A.K., and Dixon, P. 2004. How do youngsters use public libraries to find nonfiction books? The results of a recent research project. Public Library Quarterly, 23(3/4), 77-98.

Soalt, J. 2005. Bringing together fictional and informational texts to improve comprehension. The Reading Teacher, 58(7), 680-683.

Society of Children's Book Writers and Illustrators. 2005. Accessed online at http://www.scbwi.org/awards.htm, May 10, 2005.

Spink, J. 1996. Primary sources or, where the wild things aren't. School Librarian, 44(1), 11-12. 
Statistics Canada. 2005. School libraries and school librarians. Accessed online at http://www.statcan.ca/Daily/English/050504/d050504a.htm, May 6, 2005.

Stien, D., and Beed, P.L. 2004. Bridging the gap between fiction and nonfiction in the literature circle setting. The Reading Teacher, 57(6), 510-518.

Swope, M., and Katzer, J. 1972. The silent majority: why don't they ask questions? $R Q, 12(2), 161-166$.

Teale, B. 1991. Dear Readers. Language Arts, 68(6), 440-442.

The Children's Book Guild of Washington, D.C. 2005. Accessed online at http://www.scbwi.org/awards.htm, May 10, 2005.

Thorne, R., and Whitlatch, J. 1994. Patron online catalog success. College and Research Libraries, 55(6), 479-4976.

Timion, C.S. 1992. Children's book-selection strategies. In J. W. Irwin and M. A. Doyle (Eds.), Reading/writing connections: Learning from research (pp. 204222). Newark, Delaware: International Reading Association.

Tower, C. 2002. "It's a snake, you guys!": The power of text characteristics in children's responses to information books. Research in the Teaching of English, $37(1), 55-88$.

Vardell, S. 1991. A new "picture of the world": The NCTE Orbis Pictus Award for outstanding nonfiction for children. Language Arts, 68, 474-479.

Venezky, R.L. 2000. The origins of the present-day chasm between adult literacy needs and school literacy instruction. Scientific Studies of Reading, 4(1), 19-39.

Watson, J., Clayburn, M., and Snider, B. 1985. Persuasive poster power. Catholic Library World, 56(10), 423-426. 
Language and Literacy

Worthy, J. 1996. Removing barriers to voluntary reading for reluctant readers: The role of school and classroom libraries. Language Arts, 73(7), 483-492.

Worthy, J., Moorman, M., and Turner, M. 1999. What Johnny likes to read is hard to find in school. Reading Research Quarterly, 34(1), 12-27.

Worthy, J., Turner, M., and Moorman, M. 1998. The precarious place of self-selected reading. Language Arts, 75(4), 296-304.

Yopp, R.H. and Yopp, R.K. 2000. Sharing informational text with young children. Reading Teacher, 53(5), $410-423$.

\section{Biographical Note}

Patricia A. Larkin-Lieffers has a B.Sc. in Biology and a Masters in Library and Information Studies. Her interests combine these two disciplines with a focus on information books for young children and improving access to them through library design. She is presently continuing her studies at the University of Alberta. 